\title{
The influence of vibration duration on the structure of irregular RC buildings
}

\author{
Filip Pachla ${ }^{1}$ D . Alicja Kowalska-Koczwara ${ }^{1} \cdot$ Tadeusz Tatara $^{1} \cdot$ Krzysztof Stypuła $^{1}$
}

Received: 30 July 2018 / Accepted: 19 December 2018 / Published online: 1 February 2019

(c) The Author(s) 2019

\begin{abstract}
In the twenty-first century, the seismic design of buildings seems to have become a fully recognised topic. There are guidelines and standards which should be taken into account by designers in seismic areas. Designers using modern international guidelines have ascertained that the behaviour of structures is not as expected. This may be the result of not taking into account the duration of the shock. The duration of surface vibrations could be one of the basic reasons why some buildings collapse or suffer severe damage to bearing systems as a result of long-duration earthquakes despite being properly designed in accordance with current understanding. Another primary reason for such collapse or damage is that some buildings in seismic areas have irregular structural systems that are sensitive to torsional vibrations. In this paper, a five-storey, irregular-shaped RC building model was subjected to different types of excitations: mining tremors, short-duration earthquakes, long-duration earthquakes. The first stage was a modal analysis based on in situ measurement. After model verification using in situ measurements, the building was then subjected to the three forms of excitation. Numerical studies were performed using a verified FEA model of the building in the time domain. The results of the calculations prove that the duration of the intensive phase of extortion is one of the reasons for the lack of building collapse in mining areas. In cases of mining shocks with a short duration of surface vibration, damage to buildings may occur which does not threaten the safety of their construction. Building collapses occur with earthquakes which are characterised by a much longer duration of the intensive phase of excitation compared to mining shocks. The results of in situ observations of RC structures that have survived a history of mining shocks of varied intensities confirm the results of numerical analyses.
\end{abstract}

Keywords Irregular structure - Complex structure - Duration of vibration · Earthquake · Mining tremor $\cdot$ Reinforced concrete $\cdot$ Time history analysis

Filip Pachla

fpachla@pk.edu.pl

1 Faculty of Civil Engineering, Cracow University of Technology, Kraków, Poland 


\section{Introduction}

Reinforced concrete frame buildings are the most popular buildings nowadays in city centres, especially as office spaces (e.g. Paulay and Priestley 1992). The shape of such buildings is more often than not, irregular. These are no longer simply cuboid in nature; architects are trying to give them more contemporary forms. The dynamic response of building structures to earthquakes is affected by irregularities in their arrangement. Increasingly, structures with cantilever elements are created and the upper storeys protrude from the building. Such forms can constitute a problem in earthquake areas or in areas when surface vibrations come from rockbursts originating from mining activities. Soft (first) storey effect could be the reason for collapse (Bencat 2016; Cai et al. 2015; Çelebi et al. 2014; Chandramohan et al. 2016; Dolsek and Fajfar 2001; Ruiz and Diederich 1989; Sezen et al. 2003). The other cause is that irregular building structures often have solid structural components located on one side. This is the reason why irregular buildings are sensitive to torsional vibrations (Gokdemir et al. 2013). The result is that irregular buildings often suffer higher levels of damage than regular structures (Kim and Hong 2011). Torsion is a complex problem which can be analysed by a nonlinear approach using the simplified SESA method based on the superposition of modal effects with the use of overdamped displacement response spectra (Köber and Zamfirescu 2016). In Bencat (2016), the prediction method for the assessment of induced vibrations in irregular buildings is discussed.

Earthquakes are becoming increasingly stronger and of longer durations. Such a situation occurred in 1952 during the Kamchatka earthquake (Ben-Menahem and Toksöz 1963), and in 1964 in Alaska (Kanamori 1970). These earthquakes took place in remote areas and this is why they did not result in large losses; however, however, long-duration earthquakes have recently occurred in populated areas such as the sizable earthquake that occurred in the east of Japan in 2011 (Çelebi et al. 2014; Takemura et al. 2011). The effect of earthquake duration is not easy to investigate because building behaviour during earthquake could influenced by other factors like amplitude or response spectral shape. This is a subject that has been studied in different papers in the past, often with unfortunately ambiguous results (e.g. Shome et al. 1998; Tremblay and Atkinson 2001; Chai 2005). Results presented in various papers (e.g. Hancock and Bommer 2006; Iervolino et al. 2006; Dogangun 2004) have proved a lack of dependence between the duration of an earthquake and interstorey drift in building structures and positive correlation has been identified between the duration of strong earthquakes and structural damage (Hancock and Bommer 2006). The impact of the duration of ground motion on the behaviour of a structure has been found to be significantly visible for earthquakes of high intensities which cause the collapse of buildings (e.g. Belejo et al. 2017). Previous studies which have taken into consideration the effect of the duration of the records (e.g. Belejo et al. 2017) have shown that: (1) duration seems to not play an important role in terms of peak displacement responses and torsion behaviour of non-ductile reinforced concrete building; (2) the ground motion duration effects should consider the peak responses as well as number of cycles, residual deformations and energy dissipation. In turn results of investigation presented in (Hou and Qu 2015) indicated significant influence of the duration of ground motion on that of hysteretic energy dissipation demands.

Poland belongs to regions with low and very low seismic hazard but from time to time, weak earthquakes occur such as an event in 2004 in the Podhale region (Guterch et al. 2005; Zembaty et al. 2007; Wiejacz and Debski 2009). Poland, especially the south of Poland, is exposed to random mining tremors occurring as earthquakes (Zembaty 2004); 
these events are beyond human control. The maximum magnitudes of underground mining tremors are about 4.0-4.6. Such a value of magnitude can be comparable with weak earthquakes. There are however many differences between earthquakes and mining tremors (Tatara et al. 2017). The major differences are:

(i) Duration of intensive phase of vibrations - mining tremors last less than earthquakes. The duration of the intensive phase can even be ten times less.

(ii) Peak ground accelerations - mining tremors and earthquakes differ with regard to the order of magnitude. PGA for mining tremors can be about $0.3 \mathrm{~g}$ (g-acceleration of gravity) while the PGA for earthquakes may be 1-2 g (Furumura et al. 2011).

(iii) Content of predominant frequencies-generally in the case of earthquakes, the predominant frequencies are low; the predominant frequencies of ground acceleration vibrations in the case of rock bursts are in the bands up to $6.5 \mathrm{~Hz}$, from 6.5 to $12 \mathrm{~Hz}$ and higher than $12 \mathrm{~Hz}$ (sometimes even up to $40 \mathrm{~Hz}$ ) (Maciag et al. 2016).

(iv) Frequency of occurrence-strong earthquakes that cause structural damages occur in the same area with a frequency of the tens to hundreds of years. By contrast, mining tremors with a high value of PGA caused by mining activity and underground explosions occur much more often, within a few years of each other.

(v) Depths of hypocenter-mining tremors occur at much shallower depths than earthquakes; the depth of the later could be as much as $180 \mathrm{~km}$ (Kufner et al. 2017).

The most precise way to estimate the dynamic response of irregular structures subjected to earthquakes or paraseismic actions is to create 3D model and conduct a nonlinear response history analysis (RHA). However, this approach has been described as being complicated, time consuming and is not useful in practice, for example, by Erduran 2008. These shortcomings resulting in the use of non-linear static analysis procedures (NSP) which are user friendly and faster to implement (Gupta and Krawinkler 2000; Chopra and Goel 2002). Combination of pushover analysis of multi degree of freedom model (MDOF) with the response spectrum method (RSM) for an equivalent single-degree-of-freedom (SDOF) system is another nonlinear method used in earthquake analysis named as the N2 method (Fajfar and Fishinger 1988; Fajfar et al. 2002). The proposed N2 method used both acceleration-displacement formulation and inelastic spectra resulting in the possibility of a visual interpretation of the procedure. The results of the N2 method are sufficiently accurate providing that the structure vibrates predominantly with the first natural frequency. The simplified nonlinear analysis procedures used an equivalent single-degree-of-freedom (SDOF) system have also been developed and proposed by several researchers, such as Kuramoto et al. (2000) and Fajfar (2000).

Numerical models are also very useful for studying the dependence between strongmotion duration and structural damage (e.g. Barbosa et al. 2017; Chandramohan et al. 2016); this is due to providing the opportunity to separate different components of ground motion and investigating interesting aspects of the dynamic response of the structure in question.

In this article, numerical studies are presented for five-storey irregular shaped RC building models subjected to five different types of excitation in the form of recorded surface horizontal vibrations; this is due to the differences between mining tremor and earthquake phenomenon. Although many numerical studies have recently been performed to investigate structural behaviour under earthquake and mining tremor excitation (Naderpour et al. 2016; Papaloizou et al. 2016; Lu et al. 2016; Dulinska and Nowakowska 2016; Kozlowska 
et al. 2016), there is still a need to investigate and compare results of numerical analysis made on the same object, in the same soil conditions. This paper is concerned with the duration of earthquakes and mining tremor excitations and the resultant structural responses.

\section{FEA model}

The building selected for analysis is located in Cracow. It is a reinforced concrete frame, five-storey building with a system of columns and floors that is typical for such a structure. The building dimensions are 17.6 by $17.9 \mathrm{~m}$. The height of the building is $23.2 \mathrm{~m}$. The dimensions of the structural components are as follows: columns are from 25 by $25 \mathrm{~cm}$ up to 35 by $35 \mathrm{~cm}$, floor slabs are $25 \mathrm{~cm}$ thick. It is a irregular building with concrete staircases located on the north side of the building. Views of the building are presented in Fig. 1. Plans of the building and its cross section are presented in Figs. 2 and 3, respectiv ely.

The dynamic analysis of the building requires the construction of a spatial model using for example FEM (finite element method). The choice to construct a spatial model resulted from the irregularity of the position of load-bearing elements and the inability to apply simplifications in the construction of the model. The analyses were performed using DIANA FEA software (Diana 2017). The building model includes all the elements important from the point of view of stiffness and mass distribution, which determine the dynamic properties

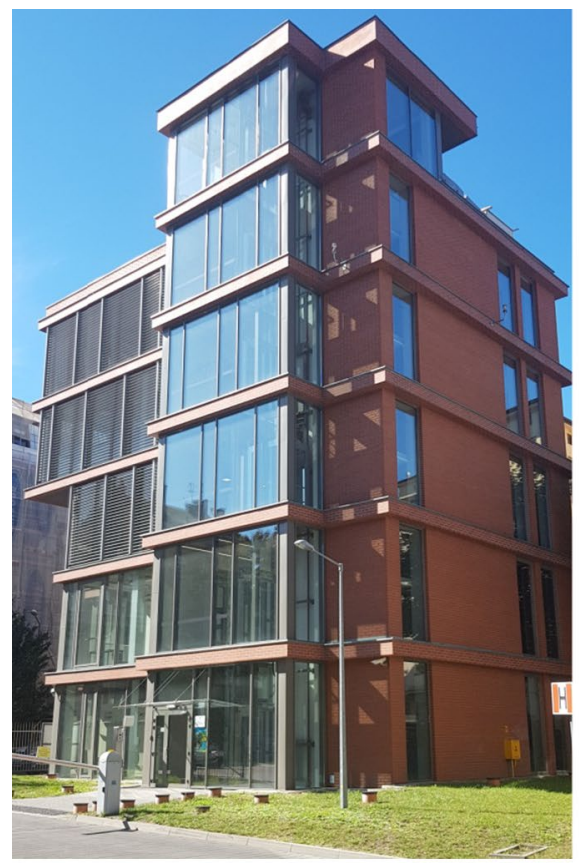

(a)

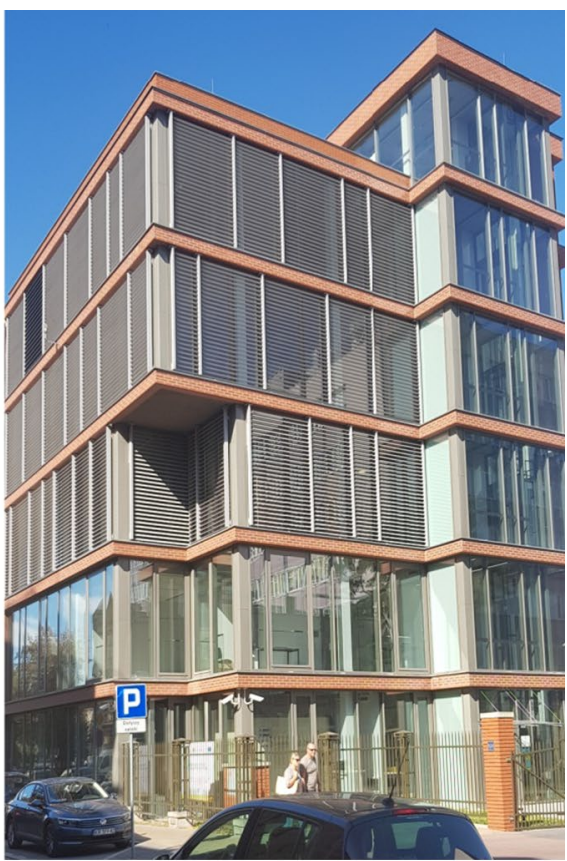

(b)

Fig. 1 View of the building: a north-east elevation, $\mathbf{b}$ south-east elevation 


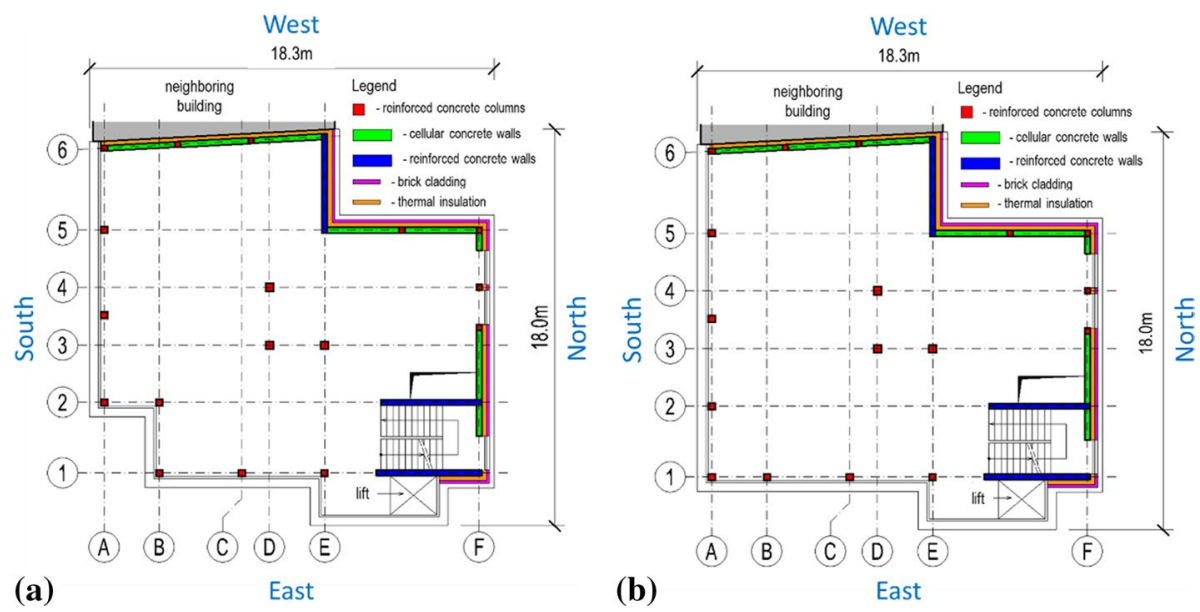

Fig. 2 Plan view of the building: a ground floor, $\mathbf{b} 4$ th floor

Fig. 3 Cross section of the building

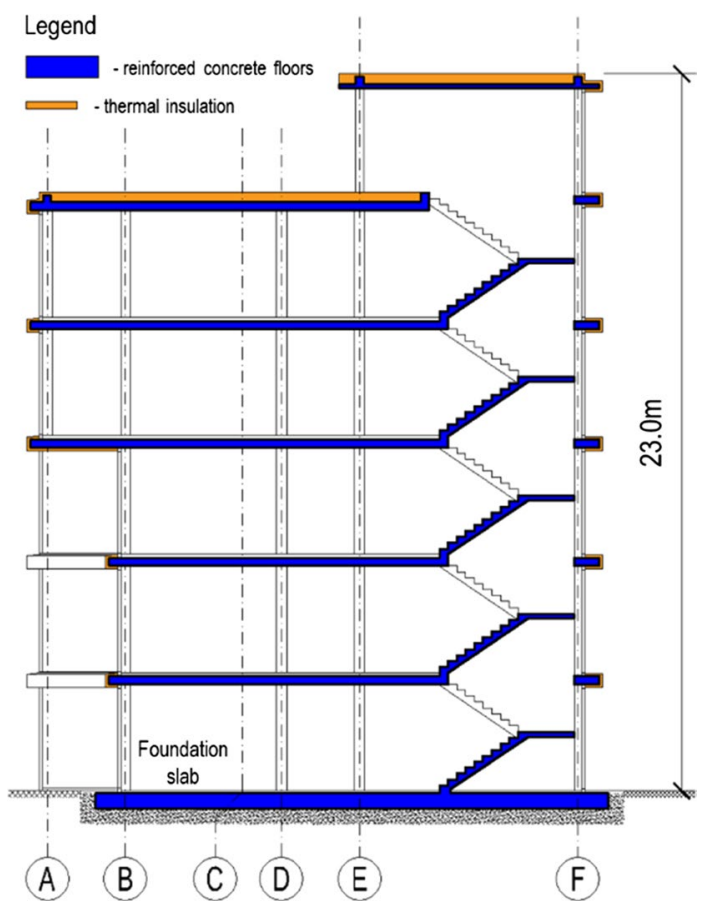

(A) (B) (D)

of the model. Support of the model at the foundation level is applied as fixed in translation and rotational degrees of freedom. Figure 4 shows the analysed structural model.

For the reinforced columns, 3-node curved beam-column elements were used. For the walls and floor slabs, a layered shell element was used. This layered shell element is composed of an 8-node quadrilateral. The 8-node quadrilateral allows the inclusion of drill rotation degree of freedom and ensures better approximation of the results. 

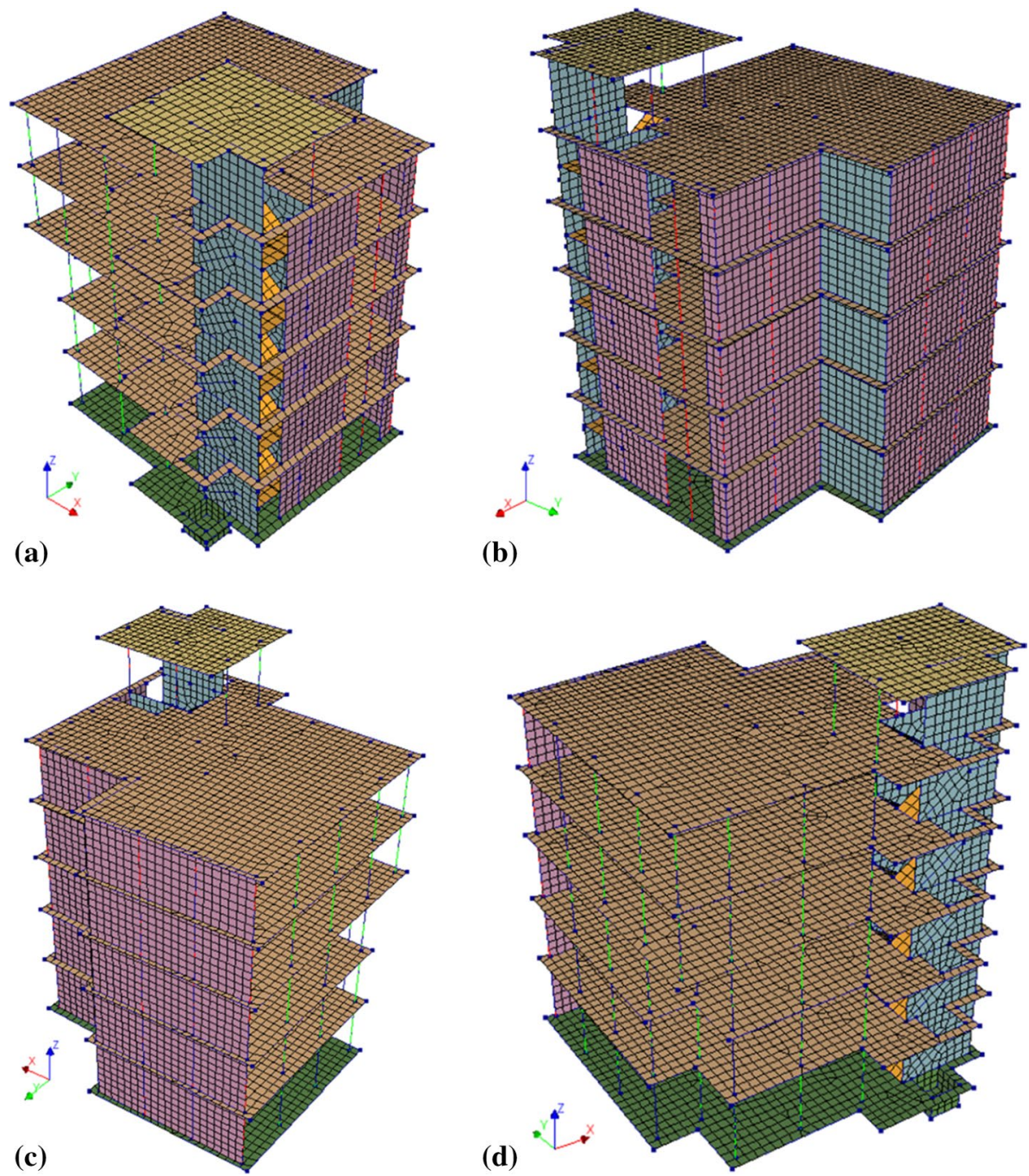

Fig. 4 FEA model of the building

A nonlinear total strain rotating crack model was assumed for concrete elements like walls, slabs, and columns. For the infill walls of cellular concrete, the same material model with different parameters was also adopted. The properties of the materials are shown in Table 1. 


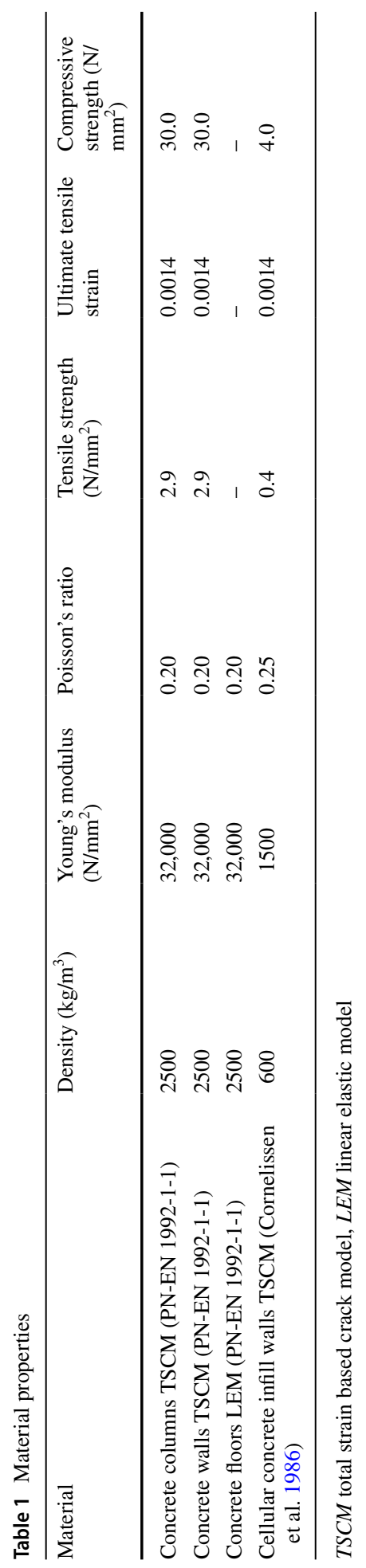




\section{Model verification and dynamic analysis}

\subsection{Natural frequencies of the model}

The natural frequencies were used to verify the model of the analysed building. The range of natural frequencies is relatively dense. The values of the first ten calculated natural frequencies with their mass participation factors are shown in Table 2. The mode shapes obtained from modal analysis are shown in Fig. 5.

The designed 3D model of the building has been subjected to experimental verification in order to compare the theoretical values of the natural frequencies with the values obtained from in situ experimental research of the building. Low values of damping in reinforced concrete buildings (Ciesielski et al. 1995) are the reason for identifying frequencies of free vibrations with their natural frequencies. The tests used several methods of generating building excitation - a modal hammer, traffic on a nearby street and controlled rides of light truck through the threshold release were used as sources of excitation for the investigated building.

Characteristics of the modal hammer are as follows:

1. PCB Model 086D50 large-sledge impulse hammer

2. sensitivity: $( \pm 15 \%) 0.23 \mathrm{mV} / \mathrm{N}$

3. measurement range: $\pm 22,240 \mathrm{~N}$

4. hammer mass: $5.5 \mathrm{~kg}$.

Preliminary results of numerical tests have shown that the values of fundamental lateral frequencies in ' $x$ ' and ' $y$ ' directions are low resulting in further the selection of appropriate measuring equipment. The measuring system consisted of PCB acceleration sensors and appropriate instrumentation. The error of the measured accelerations did not exceed $11.61 \%$. The details of the measurement method have been described in the paper by Tatara et al. (2017).

The PCB sensors were located in selected points on three levels of the building. The sensors recorded vibrations in three directions corresponding to two perpendicular

Table 2 First ten natural frequencies of the FEM model

\begin{tabular}{lcrcr}
\hline Mode & Frequency $(\mathrm{Hz})$ & \multicolumn{4}{c}{ Mass participation factor for translations } \\
\cline { 3 - 5 } & & $\mathrm{X}$ & $\mathrm{Y}$ & \multicolumn{2}{c}{$\mathrm{Z}$} \\
\hline 1 & 1.84 & $-2.58 \mathrm{E}+01$ & $8.18 \mathrm{E}+02$ & $6.52 \mathrm{E}+00$ \\
2 & 2.65 & $7.00 \mathrm{E}+02$ & $2.16 \mathrm{E}+02$ & $1.28 \mathrm{E}+01$ \\
3 & 3.35 & $-5.24 \mathrm{E}+02$ & $1.83 \mathrm{E}+02$ & $-1.03 \mathrm{E}+01$ \\
4 & 4.04 & $-1.49 \mathrm{E}+02$ & $-1.01 \mathrm{E}++02$ & $-2.33 \mathrm{E}+00$ \\
5 & 4.70 & $1.77 \mathrm{E}+02$ & $-2.81 \mathrm{E}+02$ & $-7.75 \mathrm{E}-01$ \\
6 & 7.54 & $1.81 \mathrm{E}+01$ & $3.72 \mathrm{E}+02$ & $-3.71 \mathrm{E}+01$ \\
7 & 9.28 & $-3.43 \mathrm{E}+01$ & $2.61 \mathrm{E}+01$ & $5.20 \mathrm{E}+02$ \\
8 & 11.09 & $3.03 \mathrm{E}+02$ & $-3.39 \mathrm{E}+01$ & $-7.67 \mathrm{E}+01$ \\
9 & 11.12 & $2.97 \mathrm{E}+02$ & $-6.11 \mathrm{E}+00$ & $6.22 \mathrm{E}+01$ \\
10 & 11.13 & $7.85 \mathrm{E}+01$ & $1.10 \mathrm{E}+02$ & $-9.78 \mathrm{E}+00$ \\
\hline
\end{tabular}




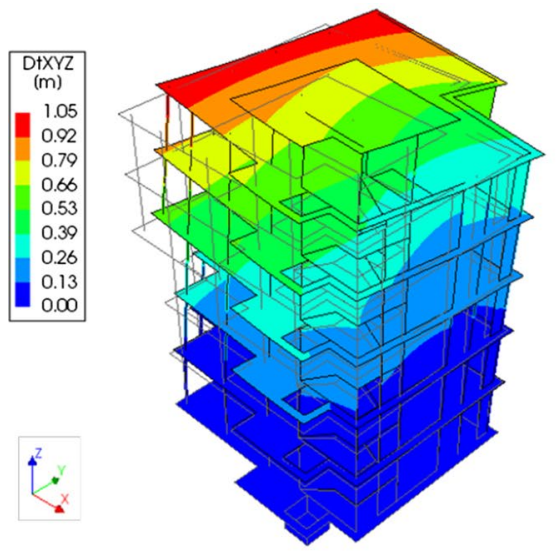

(a) Mode shape No. $1-f=1.84(\mathrm{~Hz})$ flexural in ' $y$ ' direction

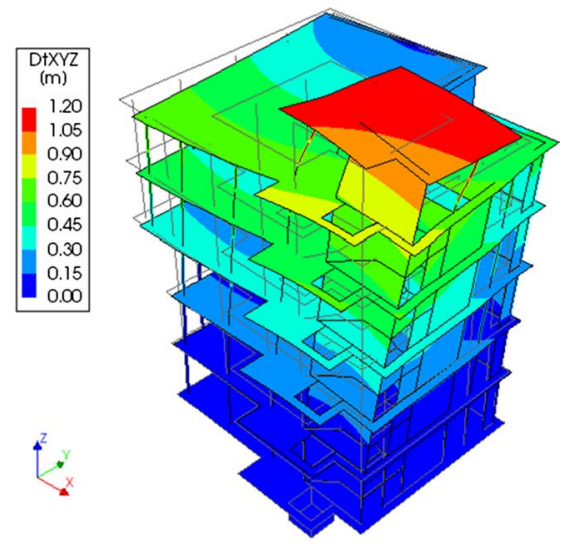

(b) Mode shape No. $2-\mathrm{f}=2.65(\mathrm{~Hz})$

flexural in ' $x$ ' direction

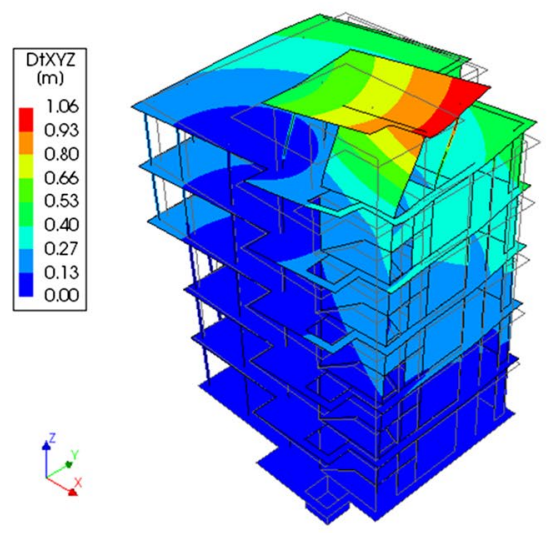

(c) Mode shape No. $3-\mathrm{f}=3.35(\mathrm{~Hz})$ - torsional

Fig. 5 First three mode shapes corresponding to the natural frequencies of the model

horizontal directions and vertical direction ' $z$ '. An example of a selected point with PCB accelerometers mounted to the bearing element of the building is shown in Fig. 6.

The analysed building is characterised by low natural vibration frequencies which resulted in the adoption of the low-pass filter with cut-off frequencies equal to 10 and $50 \mathrm{~Hz}$ for the recorded vibrations. FFT analysis of the filtered vibration records was then performed. Example results of FFT analysis of horizontal building vibrations recorded on the fourth floor due to impact of the modal hammer at the bottom of the structural column located in $1 / \mathrm{F}^{\prime}$ axis is shown in Fig. 7.

The records of free vibrations and results of their FFT analysis were the basis for determining the values of natural flexural vibrations in the horizontal directions and the frequency of torsional vibrations. The calculated and measured values of natural frequencies are compared in Table 3. Differences between the values of the calculated and measured fundamental horizontal frequencies do not exceed 3\%. Similar differences were observed for the second natural frequencies of the examined building. This was the basis for 
Fig. 6 PCB sensors located at the ground level of the structure
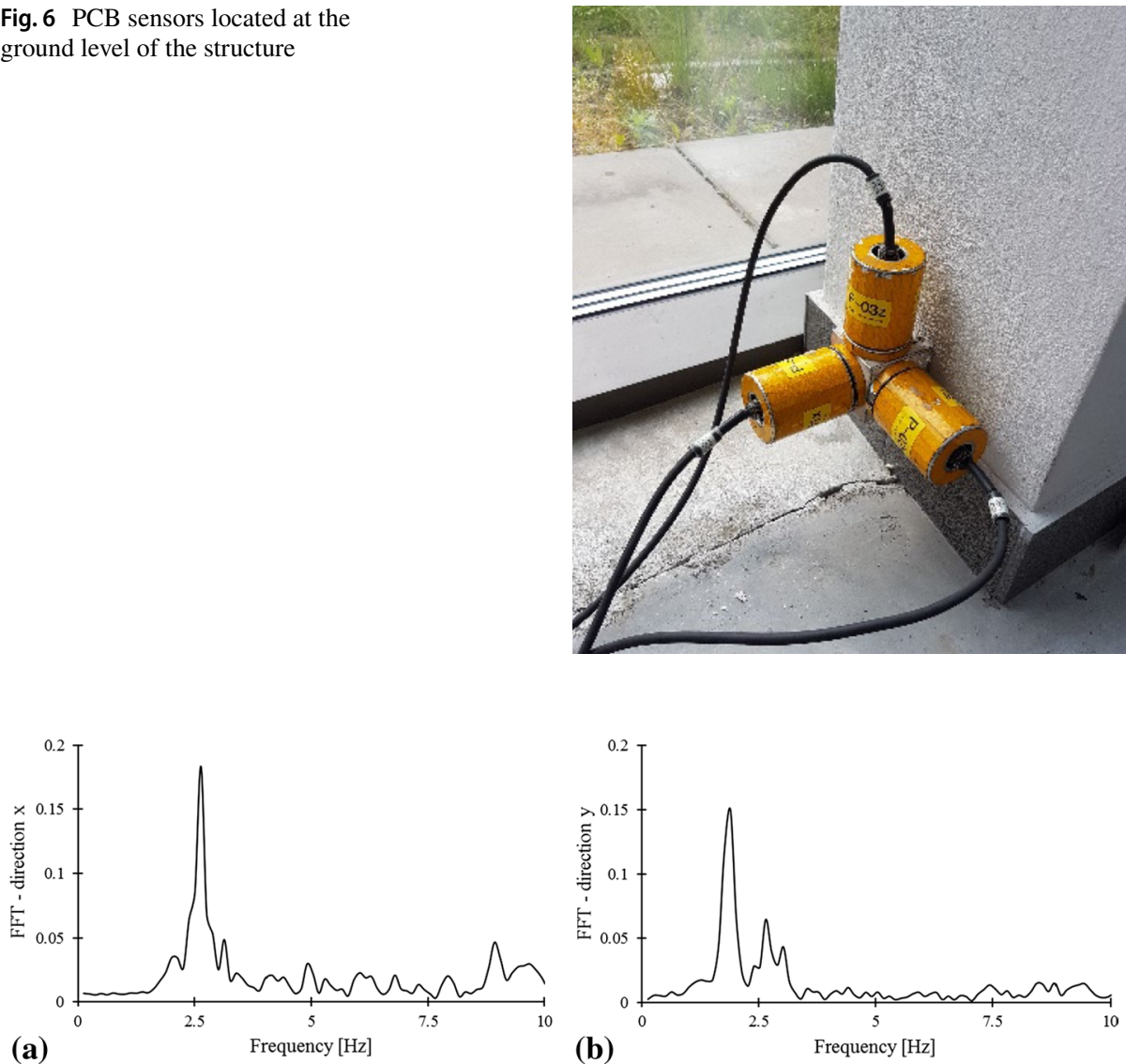

Fig. 7 Result of the FFT of the horizontal components ' $x$ ' and ' $y$ ' of the structure on the 4th floor due to the modal hammer impact in the column

Table 3 Natural frequencies of the model based on dynamic measurements $(\mathrm{Hz})$

\begin{tabular}{llll}
\hline Mode shape & $\begin{array}{l}\text { Value of frequency } \\
\text { from measurements } \\
(\mathrm{Hz})\end{array}$ & $\begin{array}{l}\text { Calculated value } \\
\text { of frequency } \\
(\mathrm{Hz})\end{array}$ & $\begin{array}{l}\text { Difference between the calculated and } \\
\text { measured values of the frequencies } \\
(\%)\end{array}$ \\
\hline Flexural in 'y' direction & $\sim 1.89$ & 1.84 & 2.7 \\
Flexural in 'x' direction & $\sim 2.62$ & 2.65 & 1.1 \\
Torsional & $\sim(2.50-3.50)$ & 3.35 & - \\
\hline
\end{tabular}

accepting the adopted model for further seismic analysis. Note that the fundamental frequencies are significant in the determination of wind load (PN-EN 1991-1-4 (191) Eurocode 1; Riera and Davenport 1998) and in results of the dynamic calculation of surface structures subjected to earthquakes and mining shocks (Tatara et al. 2017). 
In dynamic analysis, records of the horizontal components of ground acceleration vibrations caused by underground mining-related exploitation of mineral resources and earthquakes were used (see Figs. 8-12 respectively). Records of earthquakes which occurred in the district of Sitka, Alaska (1972) and in El Centro (1940) presented in Figs. 11 and 12, respectively were also applied. In Poland, mining-related surface vibrations mainly originate from the underground exploitation of hard and lignite coal and copper ore. A detailed description of the phenomenon of mining shakes in Poland is given by Tatara et al. (2017).

Mining-related wave propagation and amplification in soils have been the research interests of many authors (Driad-Lebeau et al. 2009; Semblat et al. 2000, 2005). The problem of the accumulation of the dynamic response of a rock mass disturbed by mining activities has been studied in many papers (e.g. Cai et al. 2015). In Poland, surface mining-related vibrations have a significant impact on surface and underground structures.

In Poland, the area of the Legnica-Glogowski Copper Region (LGCR) is one of the most exposed areas with regard to mining tremors. Mining tremors are characterised by a high frequency of occurrence in this area. The most numerous forms are rockbursts with energies not exceeded E7 (J). Over recent years, the intensity of mining shocks with energies exceeding E7 (J) is increasing. Such shocks generate surface vibrations with large maximum values of free-field vibrations. To date in the LGCR, mining shocks with high energy values have not resulted in fatalities as in the case of earthquakes. Mining shocks have caused material damage. Figure 10 presents, as an example, horizontal components of mining vibration caused by the most intense rocbursts with energy values of $1.9 \mathrm{E} 9(\mathrm{~J})$ in the LGCR area and results of FFT analysis. The maximum value of horizontal components ' $x$ ' and ' $y$ ' (PGAx, PGAy) of acceleration mining-related vibration are greater than corresponding components of the analysed Sitka earthquake (Figs. 10, 11 and Table 4).

The content of dominant frequencies of the analysed mining origin records is shown in Figs. 8, 9 and 10. Analysis of the FFT results of vibration records from Figs. 8, 9 and 10 indicates that the predominant frequencies of ground acceleration vibrations in all cases of rockbursts in the LGCR area are below $12 \mathrm{~Hz}$ and the highest frequencies do not exceed $25 \mathrm{~Hz}$. In the dynamic analysis of the model, we also used other records of surface mining origin corresponding to rockbursts with smaller energy values of 4.2 E6 and 1.7 E8 (J)see Figs. 8 and 9.

The duration of the intensive phase of mining origin vibrations is relatively short and does not exceed $10 \mathrm{~s}$. In the case of earthquakes, these durations are much longer and amount to several dozen seconds. For example duration of intensive phase based on Arias intensity for Sitka earthquake is 3.5 times greater than in the case of mining tremor no. 3 (see Table 4).

Values of the coefficient (PGA/PGV) indicate that the strongest mining tremors correspond to weak, shallow earthquakes. The strongest analysed mining tremor (see Fig. 10) is characterised by higher acceleration values than the analysed Sitka earthquake. As a rule, the maximum values of mining origin free-field vibration accelerations do not exceed the value of $0.30 \mathrm{~g}$ (Maciag et al. 2016). Table 4 contains data characterising the basic parameters of surface horizontal components of the analysed earthquakes and vibrations of mining origin.

The dynamic numerical analysis was performed in two stages. In the first stage, gravity loads were considered as quasi static. The nonlinear static equations of gravity were solved using the iterative Newton method available in Diana code (DIANA user manual release 10.2). In the second stage of analysis, a nonlinear THA (time history analysis) was made with earthquake records as the excitation. 


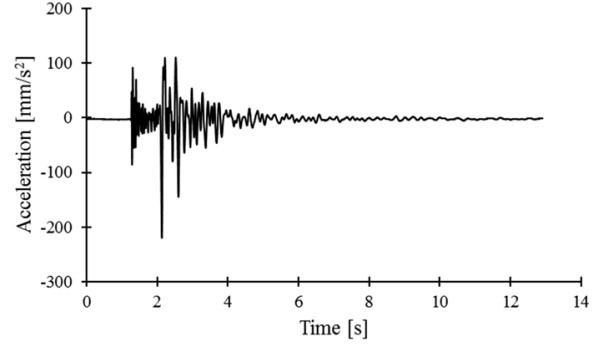

(a) Acceleration record in ' $x$ ' direction

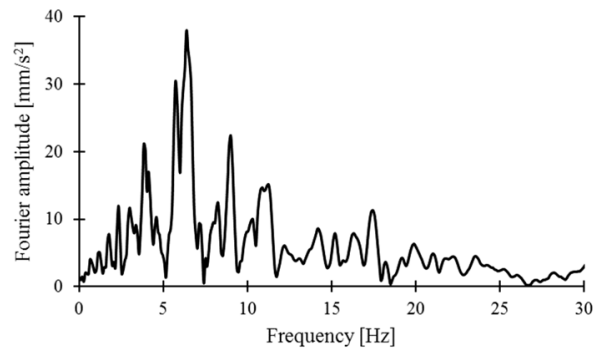

(c) FFT o acceleration record in ' $x$ ' direction

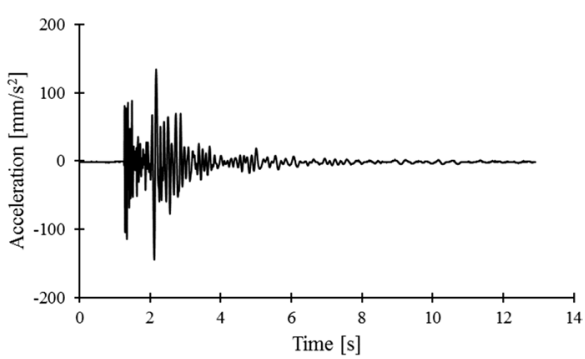

(b) Acceleration record in ' $y$ ' direction

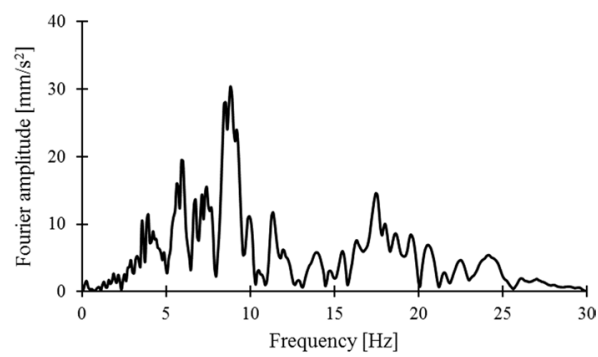

(d) FFT o acceleration record in ' $y$ ' direction

Fig. 8 The horizontal components of mining tremor no. 1

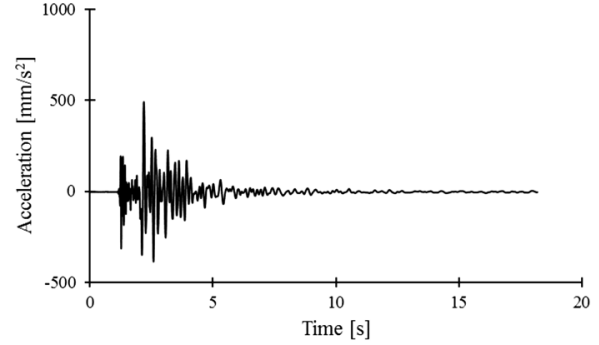

(a) Acceleration record in ' $x$ ' direction

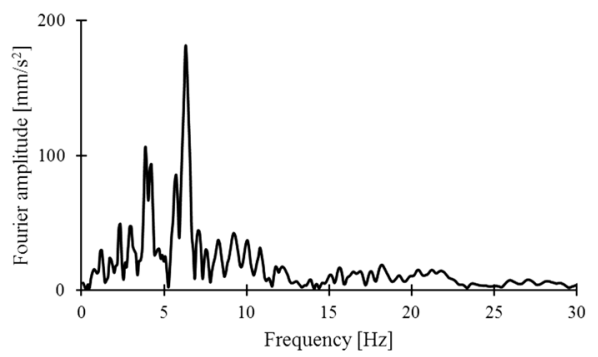

(c) FFT o acceleration record in ' $x$ ' direction

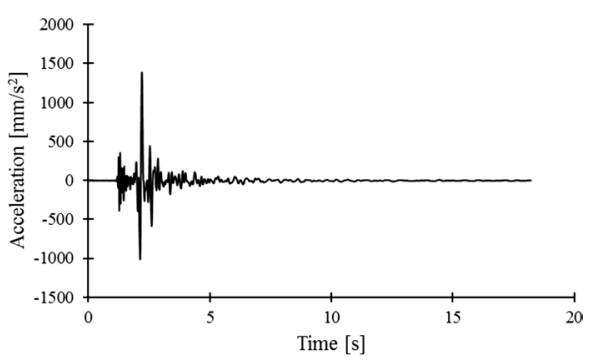

(b) Acceleration record in ' $y$ ' direction

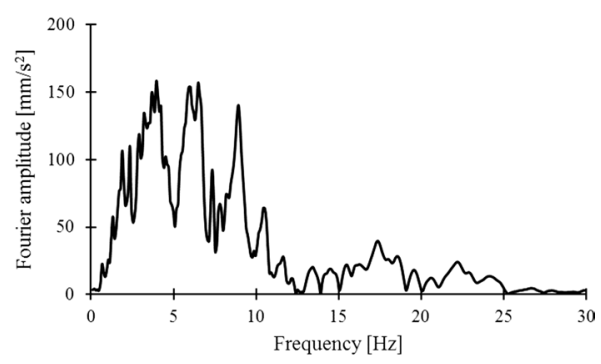

(d) FFT o acceleration record in ' $y$ ' direction

Fig. 9 The horizontal components of mining tremor no. 2 


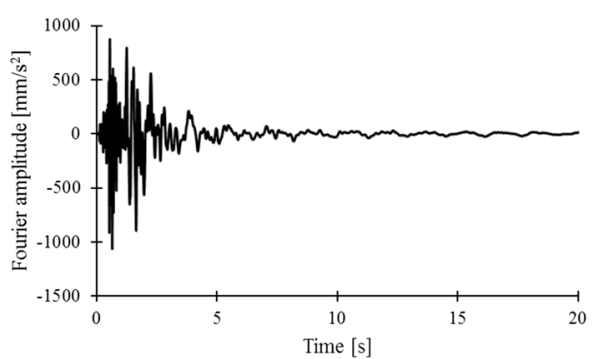

(a) Acceleration record in ' $x$ ' direction

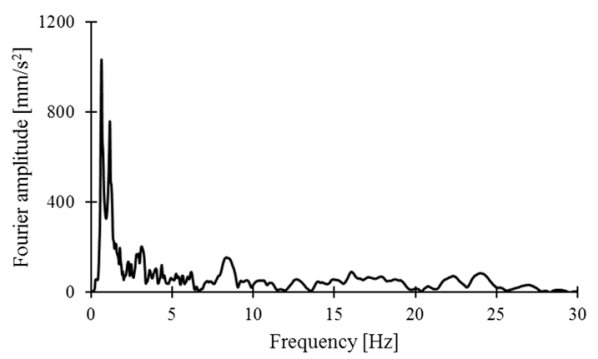

(c) FFT 0 acceleration record in ' $x$ ' direction

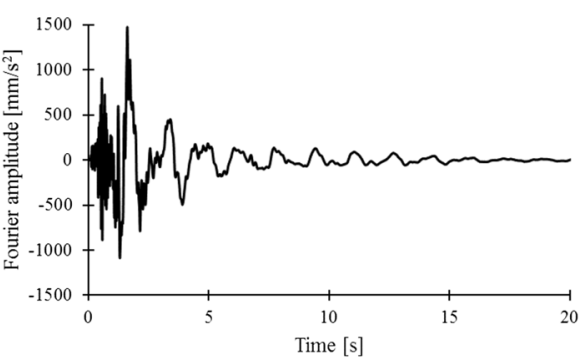

(b) Acceleration record in ' $y$ ' direction

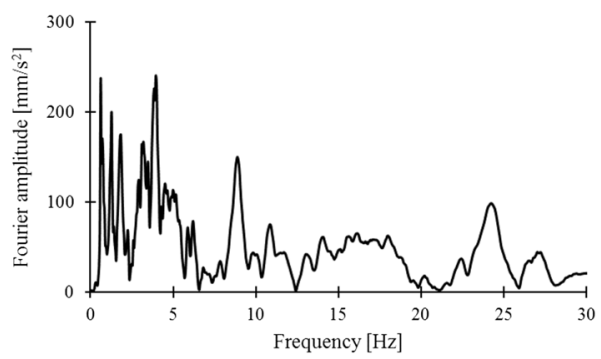

(d) FFT o acceleration record in ' $y$ ' direction

Fig. 10 The horizontal components of mining tremor no. 3

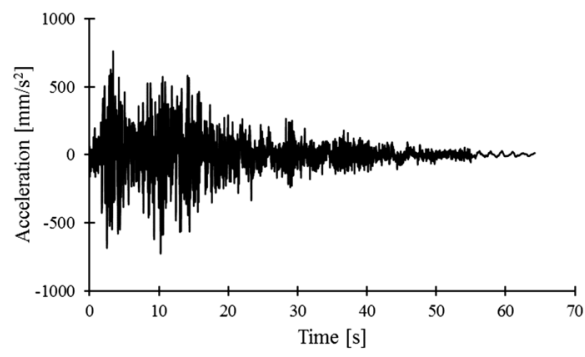

(a) Acceleration record in ' $x$ ' direction

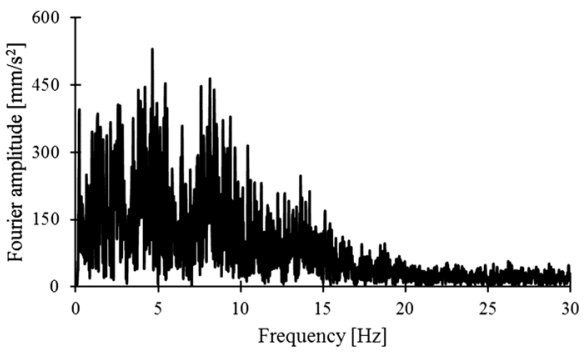

(c) FFT 0 acceleration record in ' $x$ ' direction

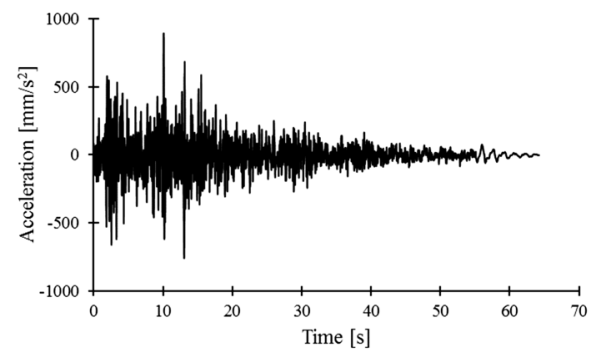

(b) Acceleration record in ' $y$ ' direction

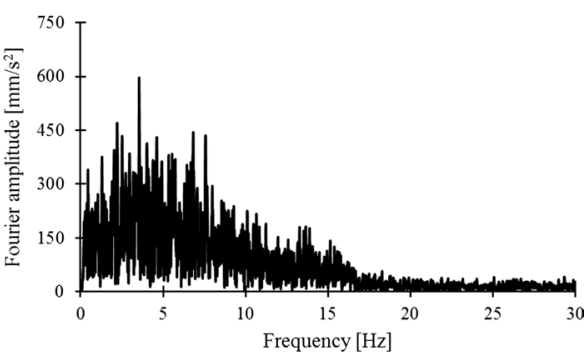

(d) FFT o acceleration record in ' $y$ ' direction

Fig. 11 The horizontal components of the Sitka earthquake 


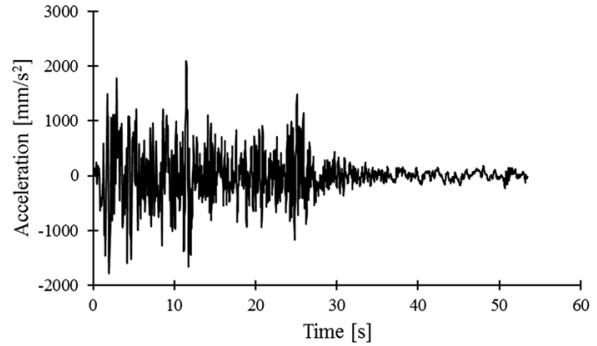

(a) Acceleration record in ' $x$ ' direction

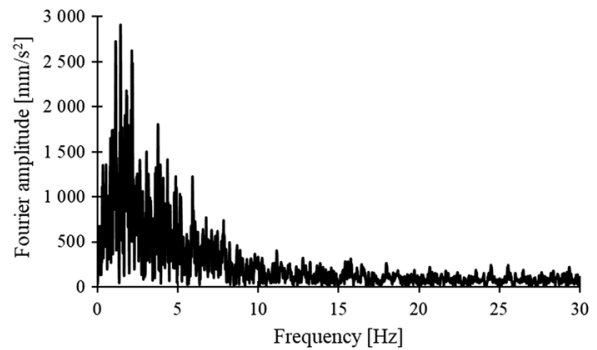

(c) FFT o acceleration record in ' $x$ ' direction

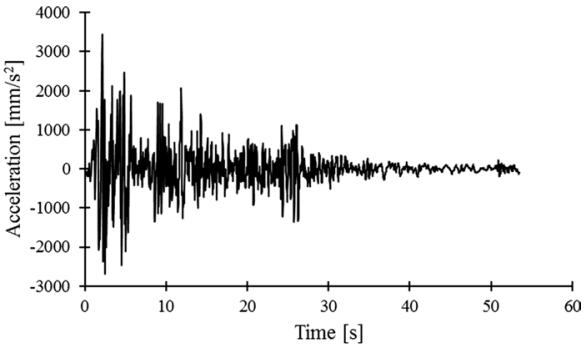

(b) Acceleration record in ' $y$ ' direction

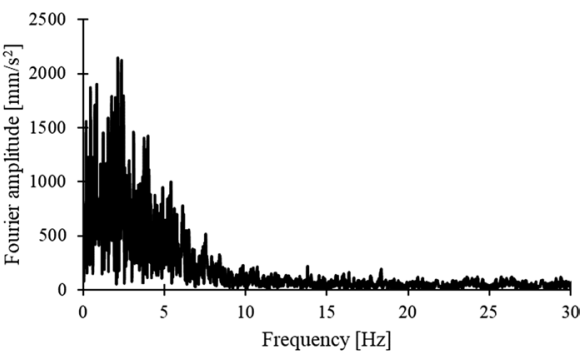

(d) FFT o acceleration record in ' $y$ ' direction

Fig. 12 The horizontal components of the El Centro earthquake

Table 4 Characteristics of the analysed components of vibrations

\begin{tabular}{lllllllll}
\hline No. & $\begin{array}{l}\mathrm{PGA}_{\mathrm{x}} \\
\left(\mathrm{mm} / \mathrm{s}^{2}\right)\end{array}$ & $\begin{array}{l}\mathrm{PGA}_{\mathrm{y}} \\
\left(\mathrm{mm} / \mathrm{s}^{2}\right)\end{array}$ & $\begin{array}{l}\mathrm{PGV}_{\mathrm{x}} \\
(\mathrm{mm} / \mathrm{s})\end{array}$ & $\begin{array}{l}\mathrm{PGV}_{\mathrm{y}} \\
(\mathrm{mm} / \mathrm{s})\end{array}$ & $\begin{array}{l}\mathrm{PGA}_{\mathrm{x}} / \mathrm{PGV}_{\mathrm{x}} \\
(1 / \mathrm{s})\end{array}$ & $\begin{array}{l}\mathrm{PGA}_{\mathrm{y}} / \mathrm{PGV}_{\mathrm{y}} \\
(1 / \mathrm{s})\end{array}$ & $\begin{array}{l}\mathrm{th}_{\mathrm{a}} * \\
(\mathrm{~s})\end{array}$ & $\begin{array}{l}\mathrm{th}_{\mathrm{v}} * * \\
(\mathrm{~s})\end{array}$ \\
\hline 1 & 144 & 220 & 3.3 & 6.9 & 43.6 & 31.9 & 2.3 & 8.0 \\
2 & 494 & 1392 & 34.4 & 58.1 & 14.4 & 23.9 & 2.1 & 3.1 \\
3 & 1054 & 1477 & 48.2 & 180.2 & 21.9 & 8.2 & 7.7 & 8.2 \\
4 & 765 & 894 & 74.2 & 67 & 10.3 & 13.3 & 27.1 & 28.9 \\
5 & 2099.3 & 3423.6 & 487.9 & 380.9 & 4.3 & 9.0 & 24.4 & 38.5 \\
\hline
\end{tabular}

*Significant duration of intensive phase of acceleration

**Significant duration of intensive phase of velocity

The Newmark method, with a constant time step of $0.005 \mathrm{~s}$, was used to integrate the equations of motion in time. The constant time step of $0.005 \mathrm{~s}$ was selected based on a preliminary convergence study with respect to the integration time step size to ensure the accuracy of the results. The quasi-Newton (secant) method based on the Broyden-Fletcher-Goldfarb-Shanno (BFGS) stiffness update method was employed as the iterative method to solve the nonlinear dynamic equilibrium equations (DIANA user manual release 10.2). At the end of each time step of analysis, the last obtained secant stiffness matrix was stored and used as the initial stiffness matrix at the first iteration of the next time step. The convergence criterion was based on the relative norm of the last displacement increment vector. 

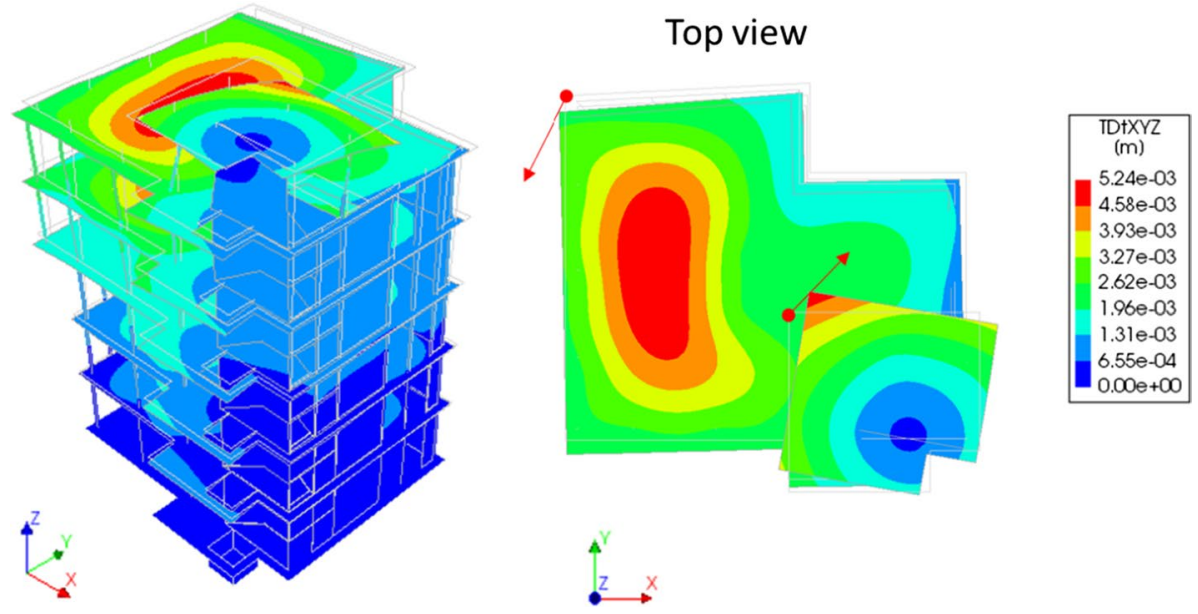

Fig. 13 Example deformation model corresponding to the maximal inclination of the structure due to mining shock-mining tremor no. 3

\section{Results of dynamic analysis}

Generally, in the dynamic analysis combination of the dead load, the dynamic load (kinematic excitation) is considered. In the present investigation the global response for the kinematic excitations was analysed. Figure 13 shows an example character of deformation at the maximum deflection of the tower due to mining shock from Fig. 10. It may be noted that the model with its high irregularity has a tendency to rotate with significant rotational deformation above the highest floor-on roof level (see Fig. 13). A similar phenomenon is observed in the case of other kinematic excitations.

After nonlinear analysis of the model, the failure modes and crack propagation can be seen in Figs. 14, 15, 16, 17 and 18. As can be observed, the crack patterns (shown using the normal principal strains) are concentrated in the staircase shaft. The walls of the staircase together with the external columns transfer the seismic horizontal forces. Major cracks propagated at the last floor where the weak and soft closing of the staircase shaft is, and around the connection with the foundation slab.
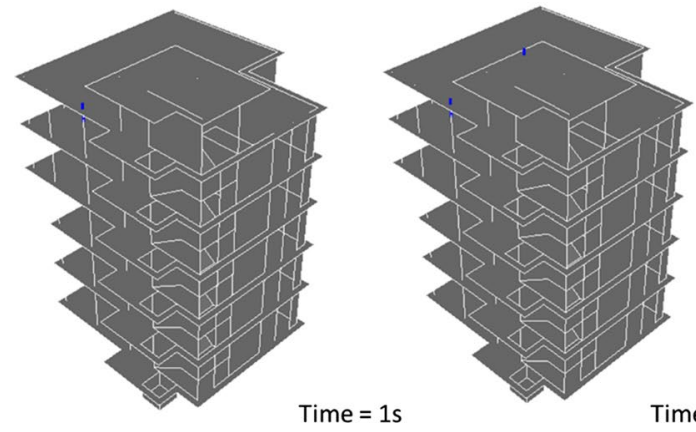

Time $=2.5 \mathrm{~s}$
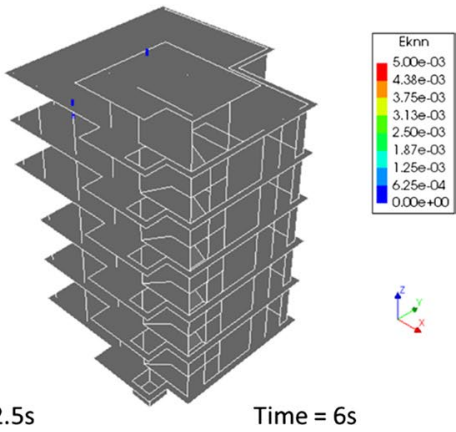

Fig. 14 Crack patterns for mining tremor no. 1 

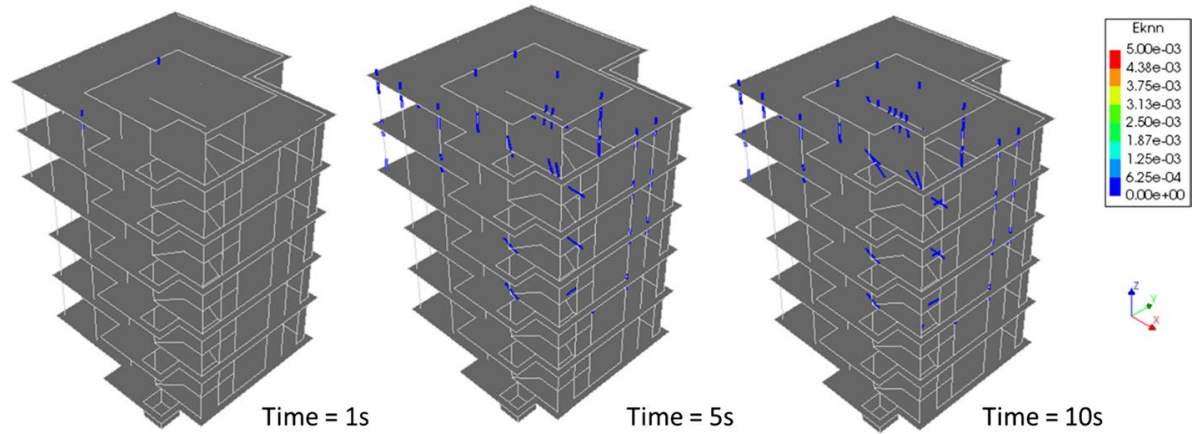

Fig. 15 Crack patterns for mining tremor no. 2
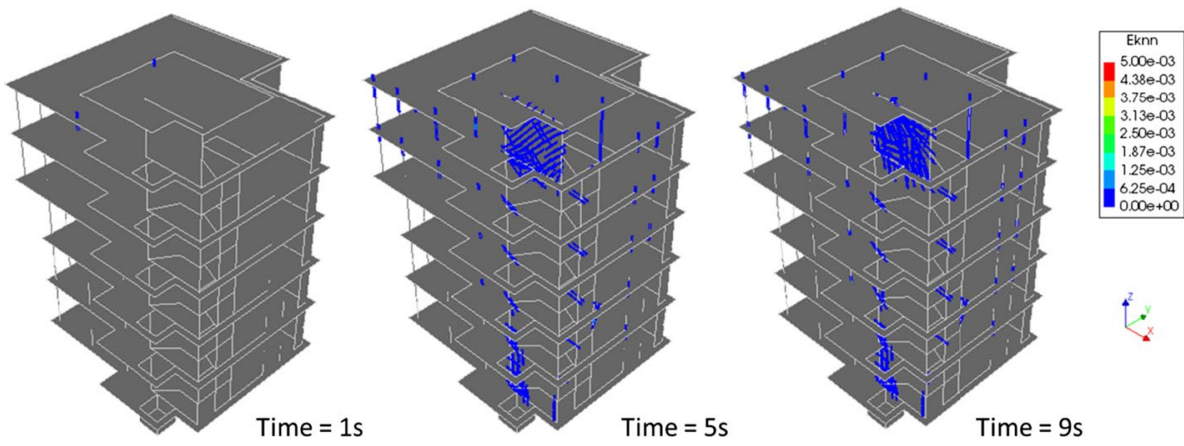

Fig. 16 Crack patterns for mining tremor no. 3
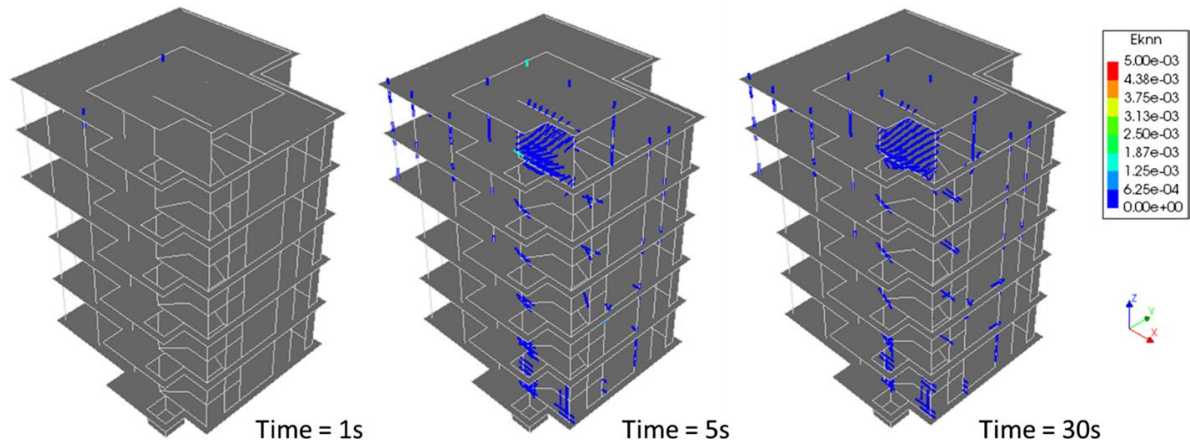

Fig. 17 Crack patterns for Sitka earthquake record

In the case of mining shock from Fig. 10, despite the short time of the intensive phase, the range of damage defined by the cracks is significant but does not lead to significant damage of the model. While in the case of the earthquake from Fig. 11, the damage range is similar, despite half the values of PGA, but much longer duration of intensive phase (Figs. 16, 17). This leads to the conclusion that the duration of the intensive phase of seismic phenomenon is very important in the dynamic response analysis of structures. The 

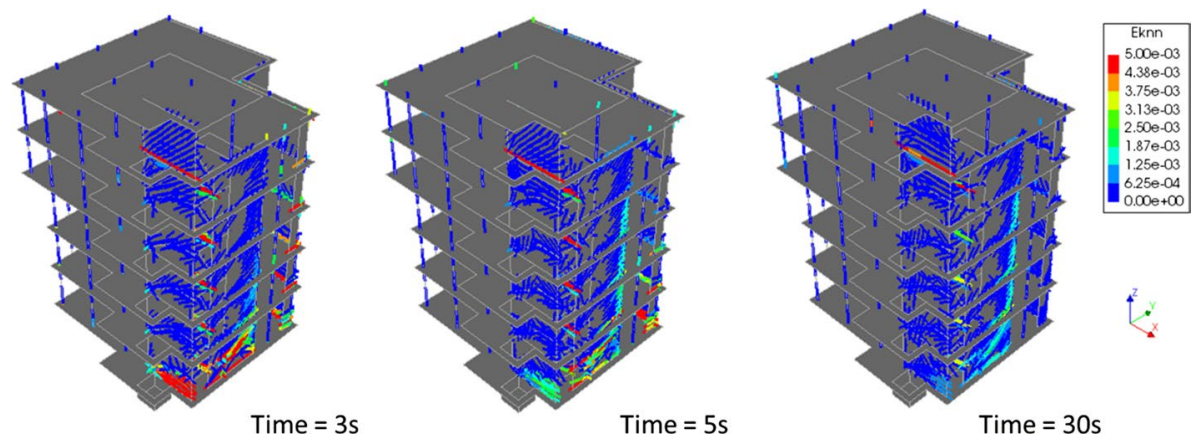

Fig. 18 Crack patterns for El Centro earthquake record

same conclusion may be drawn from the analysis of mining shock no. 2 (Fig. 9). This is a shock with a very low duration of intensive phase and PGA values greater than the earthquake shock from Sitka (Sitka record—see Fig. 11). Only local cracks of very small widths can be observed in the model (Fig. 15). A very similar cracking scenario was observed during mining tremor no. 1 with a small PGA value and a short duration of intensive phase (Fig. 14). This indicates that even relatively weak mining shocks can cause the appearance of cracks in the irregular structure.

Damage to the infill walls and reinforced concrete walls of the model can be seen in Fig. 18, after kinematic excitation from Fig. 12 (the El Centro earthquake 1940). None of adopted kinematic excitations have such PGA values, only the Sitka earthquake record have a similar duration of the intensive phase. This earthquake was one of the most intensive in history. Major cracks occurred in the concrete walls of the staircase in every floor as well as in the columns and infill walls made of cellular concrete. The crack widths exceed $1 \mathrm{~cm}$; the range of the damage is also very large. If the building was designed in the area of such interactions, its design would have to be significantly modified to withstand an earthquake of such intensity. Table 5 summarises the qualitative results of numerical modelling for all five records used for excitation.

\section{Conclusions}

In the article, five types of seismic excitation were analysed-three were mining tremors and two were earthquakes. Excitations were selected due to basic characteristics such as intensive phase duration and peak ground acceleration (PGA values).

Table 5 Summary of damage scenarios

\begin{tabular}{ll}
\hline Type of excitation & Type of damage \\
\hline Mining tremor no. 1-small PGA values, short duration & Small, local cracks \\
Mining tremor no. 2-high PGA values, short duration & Small, local cracks \\
Mining tremor no. 3-high PGA values, medium duration & Cracks in structural elements \\
Sitka earthquake-small PGA values, long duration & Cracks in structural elements \\
El Centro earthquake-very high PGA values, long duration & Damages in structural elements \\
\hline
\end{tabular}


An irregular building with a stiff staircases on its north-east side was selected for analysis and it was verified by measurement results (in situ tests) and then subjected to all five kinematic excitations. Nonlinear time-domain calculations were made. Based on the size of cracks that appeared during excitation, construction stresses were determined.

The results of calculations show a significant influence of intensive phase duration on the dynamic response of the irregular building. Comparing the first two mining tremors (the first with low PGA and the second with high PGA values), it can be seen that there are only very small local cracks (Figs. 14, 15). However, when the third form of mining tremor is considered, it can be seen that significant cracks in structural elements appeared, but they did not lead to a sudden collapse of the model (Fig. 16). This excitation differs from first two mining tremors in relation to the intensive phase duration.

The thesis of the significant influence of the intensive phase duration on the structural response of irregular building is also confirmed when comparing numerical results obtained from mining tremors no. 3 and Sitka earthquake. The records referring to Sitka earthquake have a long-term duration of the intensive phase, but the PGA values are around half that of mining tremor no. 3. The size of damage to both of these cases is similar (see Figs. 16, 18). The literature overview confirms this relationship between long-term vibrations and damage occurring in building structures (Hancock and Bommer 2006); however, in this article, it is confirmed for mining shocks. This parameter is used in the intensity scale of seismic mining events in Poland (Mutke et al. 2008; Mutke and Dubinski 2016).

In the case of very high PGA values and long duration of the intensive phase (the El Centro earthquake), the range of damages in the model is large. For such an intensive phenomenon, the structure of this irregular building should be designed according to the seismic standard.

Open Access This article is distributed under the terms of the Creative Commons Attribution 4.0 International License (http://creativecommons.org/licenses/by/4.0/), which permits unrestricted use, distribution, and reproduction in any medium, provided you give appropriate credit to the original author(s) and the source, provide a link to the Creative Commons license, and indicate if changes were made.

\section{References}

Barbosa AR, Ribeiro FLA, Neves LAC (2017) Influence of earthquake ground-motion duration on damage estimation: application to steel moment resisting frames. Earthq Eng Struct Dyn 46:27-49. https://doi. org/10.1002/eqe. 2769

Belejo A, Barbosa AB, Bento R (2017) Influence of ground motion duration on damage index-based fragility assessment of a plan-asymmetric non-ductile reinforced concrete. Eng Struct 151:682-703. https:// doi.org/10.1016/j.engstruct.2017.08.042

Bencat J (2016) Numerical and experimental prediction methods for assessment of induced vibrations in irregular buildings. In: Zembaty Z, De Stefano M (eds) Seismic behaviour and design of irregular and complex civil structures II, geotechnical, geological and earthquake engineering 40. ISBN 9783-319-14245-6 ISBN 978-3-319-14246-3 (eBook). Springer International Publishing Switzerland. ISBN1573-6059, ISNN 1872-4671 (electronic): 289-302. https://doi.org/10.1007/978-3-319-14246 $-3 \_26$

Ben-Menahem A, Toksöz MN (1963) Source mechanism from spectrums of long-period surface waves: 2. The Kamchatka earthquake of November 4, 1952. J Geophys Res 68:5207-5222. https://doi. org/10.1029/JZ068i018p05207

Cai MF, Ji HG, Wang JA (2015) Study of the time-space-strength relation for mining seismicity at Laohutai coal mine and its prediction. Int J Rock Mech Min Sci 42(1):145-151. https://doi.org/10.1016/j.ijrmm s.2004.08.001

Çelebi M, Okawa I, Kashima T, Koyama S, Iiba M (2014) Response of a tall building far from the epicenter of the 11 March 2011 M 9.0 Great East Japan earthquake and aftershocks. Struct Des Tall Spec Build 23:427-441. https://doi.org/10.1002/tal.1047 
Chai YH (2005) Incorporating low-cycle fatigue model into duration-dependent in elastic design spectra. Earthq Eng Struct Dyn 34:83-96. https://doi.org/10.1002/eqe.422

Chandramohan R, Baker JW, Deierlein GG (2016) Quantifying the influence of ground motion duration on structural collapse capacity using spectrally equivalent records. Earthq Spectra 32(2):927-950. https:// doi.org/10.1193/122813EQS298MR2

Chopra AK, Goel RK (2002) A modal pushover procedure for estimating seismic demands for buildings. Earthq Eng Struct Dyn 31:561-582. https://doi.org/10.1002/eqe.144

Ciesielski R, Kuzniar K, Maciag E, Tatara T (1995) Damping of vibration in precast buildings with bearing concrete walls. Arch Civ Eng 41(3):329-341

Cornelissen HAW, Hordijk DA, Reinhardt HW (1986) Experimental determination of crack softening characteristics of normalweight and lightweight concrete. HERON 31(2):45-56

DIANA (2017) Finite Element Analysis User's Manual release 10.2

Dogangun A (2004) Performance of reinforced concrete buildings during the May 1, 2003 Bingöl Earthquake in Turkey. Eng Struct 26:841-856. https://doi.org/10.1016/j.engstruct.2004.02.005

Dolsek M, Fajfar P (2001) Soft storey effects in uniformly infilled reinforced concrete frames. J Earthq Eng 5:1-12. https://doi.org/10.1142/S1363246901000315

Driad-Lebeau L, Lokmane N, Semblat JF, Bonnet G (2009) Local amplification of deep mining induced vibrations part 1: experimental evidence for site effects in a coal basin. Soil Dyn Earthq Eng 29(1):39-50. https://doi.org/10.1016/j.soildyn.2008.01.014

Dulinska J, Nowakowska K (2016) Influence of structural irregularities of tserkov building on its dynamic behavior under induced seismic shock of mining origin. Key Eng Mater 703:365-370. https://doi.org/10.4028/www.scientific.net/KEM.703.365

Erduran E (2008) Assessment of current nonlinear static procedures on the estimation of torsional effects in low-rise frame buildings. Eng Struct 30:2548-2558. https://doi.org/10.1016/j.engst ruct.2008.02.008

Fajfar P (2000) A nonlinear analysis method for performance-based seismic design. Earthq Spectra 16(3):573-592. https://doi.org/10.1193/1.1586128

Fajfar P, Fishinger M (1988) N2 — a method for non-linear seismic analysis of regular buildings. In: Proceedings of 9th World Conference on Earthquake Engineering, Tokyo-Kyoto, Japan, vol V, pp V-111-116

Fajfar P, Kilar V, Marušić D, Peruš I, Magliulo G (2002) The extension of the N2 method to asymmetric buildings. In: Proceedings of 4th Forum on Implications of Recent Earthquakes on Seismic Risk, Technical Report TIT/EERG 02-1, Tokyo Institute of Technology, Tokyo, Japan, pp 291-308

Furumura T, Takemura S, Noguchi S, Takemoto T, Maeda T, Iwai K, Padhy S (2011) Strong ground motions from the 2011 off-the Pacific-Coast-of-Tohoku, Japan $(\mathrm{Mw}=9.0)$ earthquake obtained from a dense nationwide seismic network, Landslides 8, pp 333-338

Gokdemir H, Ozbasaran H, Dogan M, Unluoglu E, Albayrak U (2013) Effects of torsional irregularity to structures during earthquakes. Eng Fail Anal 35:713-717. https://doi.org/10.1016/j.engfailana 1.2013.06.028

Gupta A, Krawinkler H (2000) Estimation of seismic drift demands for frame structures. Earthquake Eng Struct Dynam 29(9):1287-1305

Guterch B, Lewandowska-Marciniak H, Janusz Niewiadomski J (2005) Earthquakes recorded in Poland along the Pieniny klippen belt, Western Carpathians. Acta Geophys Pol 53(1):27-45

Hancock J, Bommer JJ (2006) A state-of-knowledge review of the influence of strong-motion duration on structural damage. Earthq Spectra 22(3):827-845. https://doi.org/10.1193/1.2220576

Hou H, Qu B (2015) Duration effect of spectrally matched ground motions on seismic demands of elastic perfectly plastic SDOFS. Eng Struct 90:48-60. https://doi.org/10.1016/j.engstruct.2015.02.013

Iervolino I, Manfredi G, Cosenza E (2006) Ground motion duration effects on nonlinear seismic response. Earthq Eng Struct Dyn 35:21-38. https://doi.org/10.1002/eqe.529

Kanamori H (1970) The Alaska Earthquake of 1964: radiation of long-period surface waves and source mechanism. J Geophys Res 75:5029-5040. https://doi.org/10.1029/JB075i026p05029

Kim J, Hong S (2011) Progressive collapse performance of irregular buildings. Struct Des Tall Spec Build 20:721-734. https://doi.org/10.1002/tal.575

Köber D, Zamfirescu D (2016) Seismic response trends of SDOF plan irregular structures. Simplified approach. In: Zembaty Z, De Stefano M (eds) Seismic behaviour and design of irregular and complex civil structures II, geotechnical, geological and earthquake engineering 40. ISBN 978-3-319-14245-6 ISBN 978-3-319-14246-3 (eBook). Springer International Publishing Switzerland. ISBN1573-6059, ISNN 1872-4671 (electronic): 233-242. https://doi.org/10.1007/978-3-319-14246-3_21

Kozlowska M, Orlecka-Sikora B, Rudzinski L, Cielesta S, Mutke G (2016) A typical evolution of seismicity patterns resulting from the coupled natural, human-induced and coseismic stresses in a longwall coal mining environment. Int J Rock Mech Min Sci 86:5-15. https://doi.org/10.1016/j.ijrmms.2016.03.024 
Kufner SK, Schurr B, Haberland Ch, Zhang Y, Saul J, Ischuk A, Oimahmadov I (2017) Zooming into the Hindu Kush slab break-off: a rare glimpse on the terminal stage of subduction. Earth Planet Sci Lett 461:127-140. https://doi.org/10.1016/j.epsl.2016.12.043

Kuramoto H, Teshigawara M, Okuzono T, Koshika N, Takayama M, Hori T (2000) Predicting the earthquake response of buildings using equivalent single degree of freedom system. In: Proceedings of 12th World Conference on Earthquake Engineering, Auckland, New Zealand. Paper Ref. 1039

Lu Z, Chen X, Lu X, Yang Z (2016) Shaking table test and numerical simulation of an RC frame-core tube structure for earthquake-induced collapse. Earthq Eng Struct Dyn 45:1537-1556. https://doi. org/10.1002/eqe. 2723

Maciąg E, Kuzniar K, Tatara T (2016) Response spectra of the ground motion and building foundation vibrations excited by rockbursts in the LGC region. Earthq Spectra 32(3):1769-1791. https://doi. org/10.1193/020515eqs022m

Mutke G, Dubinski J (2016) Seismic intensity induced by mining in relation to weak earthquakes. In: Proceedings of 24th World Mining Congress, Rio de Janeiro, Brasil, pp 419-426

Mutke G, Dubinski J, Baranski A, Lurka A (2008) Intensity scale of mining seismic events-GSIGZW. In: International Conference: Near Surface 2008-Proceedings of 14th European Meeting of Environmental and Engineering Geophysicists: Near Surface Geoscience. https://doi.org/10.3997/22144609.20146266

Naderpour H, Barros RC, Khatami SM, Jankowski R (2016) Numerical study on pounding between two adjacent buildings under earthquake excitation. Shock Vib; 2016: article ID 1504783, 9 pp. https://doi. org/10.1155/2016/1504783

Papaloizou L, Polycarpou P, Komodromos P, Hatzigeorgiou GD, Beskos DE (2016) Two-dimensional numerical investigation of the effects of multiple sequential earthquake excitations on ancient multidrum columns. Earthq Struct 10:495-521. https://doi.org/10.12989/eas.2016.10.3.495

Paulay T, Priestley MJN (1992) Seismic design of reinforced concrete and masonry buildings. Wiley, Hoboken

PN-EN 1991-1-4 (191) Eurocode 1-influence on constructions, part 1-4: general influence-wind influence

Riera JD, Davenport AG (1998) Wind effects on buildings and structures. In: Proceedings of the jubilee conference on wind effects on buildings and structures. Balkema, Rotterdam

Ruiz SE, Diederich R (1989) The Mexico earthquake of September 19, 1985-the seismic performance of buildings with weak first storey. Earthq Spectra 5(1):89-102. https://doi.org/10.1193/1.1585512

Semblat JF, Duval AM, Dangla P (2000) Numerical analysis of seismic wave amplification in Nice (France) and comparisons with experiments. Soil Dyn Earthq Eng 19(5):347-362. https://doi.org/10.1016/ S0267-7261(00)00016-6

Semblat JF, Kham M, Parara E, Bard PY, Pitilakis K, Makra K, Raptakis D (2005) Seismic wave amplification: basin geometry vs soil layering. Soil Dyn Earthq Eng 25(7-10):529-538. https://doi. org/10.1016/j.soildyn.2004.11.003

Sezen H, Whittaker AS, Elwood KJ, Mosalam KM (2003) Performance of reinforced concrete buildings during the August 171999 Kocaeli, Turkey earthquake, and seismic design and construction practice in Turkey. Eng Struct 25:103-114. https://doi.org/10.1016/S0141-0296(02)00121-9

Shome N, Cornell CA, Bazzurro P, Eduardo Carballo JE (1998) Earthquakes, records, and nonlinear responses. Earthq Spectra 14:469-500. https://doi.org/10.1193/1.1586011

Takemura S, Noguchi S, Takemoto T, Maeda T, Iwai K, Padhy S (2011) Strong ground motions from the 2011 off-the Pacific-Coast-of-Tohoku, Japan ( $\mathrm{Mw}=9.0)$ earthquake obtained from a dense nationwide seismic network. Landslides 8:333-338. https://doi.org/10.1007/s10346-011-0279-3

Tatara T, Pachla F, Kubon P (2017) Experimental and numerical analysis of an industrial RC tower. Bull Earthq Eng 15:2149-2171. https://doi.org/10.1007/s10518-016-0053-y

Tremblay R, Atkinson GM (2001) Comparative study of the inelastic seismic dem and of eastern and western Canadian sites. Earthq Spectra 17:333-358. https://doi.org/10.1193/1.1586178

Wiejacz P, Debski W (2009) Podhale, Poland, earthquake of November 30, 2004. Acta Geophys 57(2):346366. https://doi.org/10.2478/s11600-009-0007-8

Zembaty Z (2004) Rockburst induced ground motion—a comparative study. Soil Dyn Earthq Eng 24:11-23. https://doi.org/10.1016/j.soildyn.2003.10.001

Zembaty Z, Jankowski R, Cholewicki A, Szulc J (2007) Earthquakes in Poland in 2004 (in polish). Czasopismo Techniczne 2-B:115-126

Publisher's Note Springer Nature remains neutral with regard to jurisdictional claims in published maps and institutional affiliations. 